Eur Neurol 2007; $58: 191$

DOI: $10.1159 / 000104725$

\section{Change of Dialect after Stroke: A Variant of Foreign Accent Syndrome}

\author{
Jo Verhoeven ${ }^{a}$, Peter Mariën ${ }^{b}$ \\ ${ }^{a}$ City University London, London, UK; ${ }^{b}$ Middelheim General \\ Hospital Antwerp and Free University Brussels, Brussels, \\ Belgium
}

Dear Sir,

Kwon and Kim [1] report a new case of foreign accent syndrome (FAS) which we have read with great interest. This case is presented as unique in that the impression of the accent on the listener is not one of foreignness but rather one of regional accent (dialect), and on the basis of this observation, it is argued that dialect change possibly has to be considered as a variant of FAS. Although it is quite true that the majority of patients with FAS are perceived as foreign, we should like to point out that the perception of a change in regional accent has been reported on several occasions before. In fact the very first FAS case ever described by Pierre Marie in 1907 [2] reportedly involved a change in regional accent: a speaker of Parisian French developed a distinct Alsatian accent. We think it is also appropriate to refer to Critchley [3], who discusses the cases of three female native speakers of Standard British English who acquired a distinct Welsh accent, which in all three was related to deviant use of intonation. In the first patient, the accent was ascribed to dysarthria after local damage to the articulatory mechanism. The second right-handed patient developed a Welsh accent after stroke with left hemiplegia. Critchley [3] explicitly states that 'she could give no explanation for this manner of speech, for she was born and brought up in the West Country and had never visited Wales. No Welsh nurses or doctors had attended her in hospital. She had no close Welsh friends. At school none of her teachers had come from Wales' (p. 187). The third patient developed aphasia after stroke and started using a high-pitched, sing-song and distinctly Welsh intonation. More recent examples involving a change in regional accent are found in Dankovicova et al. [4], Reeves and Norton [5], Ryalls and Whiteside [6] and Seliger et al. [7], where regional variants of English (American English, Southern British English) change perceptually into other regional variants of the same language (Scottish English, Northern Irish English, Australian English).
Besides the issue of the uniqueness of the dialect change, Kwon and Kim [1] also point out that the patient observed a sustained infarct in the temporoparietal area resulting in a prosodic change and fluent aphasia. FAS occurring after a posteriorly located lesion is indeed rare but has been reported before. Aside from Roth et al. [8], we would like to refer to a study by Lippert-Gruener et al. [9] and one by Hwang et al. [10]. The former reported a German female patient with dysprosodia after a left post-traumatic haemorrhagic lesion in the temporal lobe, while the latter incurred a foreign accent without clear neurological cause but with a small transient perfusion deficit in the left lateral temporal lobe with contralateral cerebellar diaschisis. The main characteristics of the foreign accent of this patient were substantial problems with the tones of Mandarin Chinese.

\section{References}

1 Kwon M, Kim JS: Change of dialect after stroke: a variant of foreign accent syndrome. Eur Neurol 2006;56:249-252.

2 Whitaker H: Levels of impairment in disorders of speech; in Malatesha RN, Hartlage, LC (eds): Neuropsychology and Cognition. The Hague, Martinus Nijhoff, 1982, pp 168-207.

3 Critchley M: Regional 'accent', demotic speech, and aphasia; in Livre Jubilaire de Ludo van Bogaert. Antwerp, 1964, pp 182-191.

4 Dankovicova J, Gurd JM, Marshall JC, MacMahon MKC, Stuart-Smith J, Coleman JS, Slater A: Aspects of non-native pronunciation in a case of altered accent following stroke (foreign accent syndrome). Clin Linguist Phon 2001;15:195-218.

5 Reeves RR, Norton JW: Foreign accent-like syndrome during psychotic exacerbations. Neuropsychiatry Neuropsychol Behav Neurol 2001; 14:135-138.

6 Ryalls J, Whiteside J: An atypical case of foreign accent syndrome. Clin Linguist Phon 2006;20:157-162.

7 Seliger GM, Abrams GM, Horton A: Irish brogue after stroke. Stroke 1992;23:1655-1666.

8 Roth EJ, Fink K, Cherney LR, Hall KD: Reversion to a previously learned foreign accent after stroke. Arch Phys Med Rehabil 1997;78: 550-552.

9 Lippert-Gruener M, Weinert U, Greisbach T, Wedekind C: Foreign accent syndrome following traumatic brain injury. Brain Inj 2005;19: 955-958.

10 Hwang CS, Lin MH, Lin SK: Pure foreign accent syndrome: a case report. Acta Neurol Taiwan 2001;10:196-201.

\section{Jo Verhoeven}

City University London

Department of Language and Communication Science

Northampton Square, London EC1V 0HB (UK)

Tel. +44 207040 0148, Fax +44 2070408577

E-Mail jo.verhoeven@city.ac.uk

\section{KARGER}

Fax +41613061234 E-Mail karger@karger.ch www.karger.com
C 2007 S. Karger AG, Basel

0014-3022/07/0583-0191\$23.50/0 